\title{
Rooibos Tea (Aspalathus Linearis) Extract Protects against Air Particulate Matter induced Hepatic Oxidative Stress in Nrf2-independent Manner
}

\author{
LAWAL, AO \\ Bioinformatics and Molecular Biology Unit, Department of Biochemistry, School of Sciences, Federal University of Technology, Akure, \\ P.M.B. 704, Akure, Ondo-State, Nigeria. Tel: +2439056489869 \\ Email:lawalao@futa.edu.ng; tolekan@hotmail.com
}

\begin{abstract}
Diesel exhaust particles (DEP) are a typical example of air particulate matter generated into the environment from industrial, residential and vehicular diesel engines. Studies have implicated the induction of oxidative stress in the adverse health effect of DEP. In this study, the effect of aqueous rooibos extract (RE) on DEP-induced hepatic oxidative stress was examined and the role of Nrf2-regulation in this effect was evaluated. Wistar rats were divided into 4 groups of 5 rats/group and were administered $0.7 \mathrm{mg} / \mathrm{kg}$ DEP subcutaneously and $50 \mathrm{mg} / \mathrm{kg}$ RE orally. Group one was given vehicle (saline and DMSO), group two was administered with RE for 4 weeks, group three was given RE for 2 weeks followed by concomitant administration of RE and DEP for further 2 weeks and group four was given DEP twice a week at the last 2 weeks of treatment. Malondialdehyde (MDA), Conjugated dienes (CDs) and GSH levels were determined in the liver homogenate. AST and ALT activities were assayed in the serum and RT-qPCR was used to quantify the gene expression of Nrf2 and HO-1 in the liver. Results showed that RE pre-treatment significantly $(\mathrm{p}<0.001)$ decreased DEP-induced elevated serum AST and ALT levels, decreased DEP-induced MDA $(\mathrm{p}<0.001)$ and CDs $(\mathrm{p}<0.05)$ levels.DEP caused significant $(\mathrm{p}<0.05)$ decrease in GSH levels, which was reversed by rooibos extract pre-treatment. DEP also caused significant induction in Nrf2 and HO-1 mRNA levels. However, these inductions were significantly attenuated by RE. In summary, rooibos extract has the potential to protect against DEP-induced oxidative stress in hepatic tissues probably by a mechanism which may not involve activation of the Nrf2-dependent response.
\end{abstract}

\section{DOI: https://dx.doi.org/10.4314/jasem.v23i5.28}

Copyright: Copyright $\odot 2019$ Lawal. This is an open access article distributed under the Creative Commons Attribution License (CCL), which permits unrestricted use, distribution, and reproduction in any medium, provided the original work is properly cited.

Dates: Received: 24 March 2019; Revised: 20 April 2019; Accepted 23 May 2019

Keywords: Oxidative stress; diesel exhaust particles; rooibos tea; hepatic tissue

Diesel exhaust particles (DEP) are a typical example of air particulate matter released into the atmosphere from incomplete combustion of diesel in diesel engines. Epidemiological and experimental studies have shown that DEP exposure causes damage to different tissues such as the heart, kidney, lung and liver (Yoshizaki et al., 2010; Lawal et al., 2016). These adverse effects have been attributed to its ability to induce oxidative stress (Dybdahl et al., 2003; Yin et al., 2013; Miller et al., 2013). Both in vitro and in vivo studies have shown that DEP induced reactive oxygen production, lipid peroxidation, production of aldehydes, GSH: GSSG depletion and induction of HO-1(Lawal et al., 2016; Tobwala et al., 2013; Tseng et al., 2015). We have shown that DEP exposure induced ROS, HO-1 gene expression, lipid peroxidation in both cell line and animal studies (Lawal et al., 2015; Miller et al., 2013).Many studies have shown that antioxidants are capable of protecting the cells against free radical attack and oxidative stress (Pradedova et al., 2011; Lawal et al., 2016). Many phytochemicals derived from plant have been shown to exhibit antioxidant property and thus have been used in many studies to protect or attenuate against free radical attack (Marnewick et al., 2011). Plant with such antioxidant property is Rooibos (Aspalathus linearis) tea, a plant native of cape floral kingdom in South Africa (Joubert et al., 2008). This tea is

Email:tolekan@hotmail.com commercially available in packs in many local shops and shopping malls in Nigeria and around the world. Rooibos tea has been reported to exhibit antioxidant, antimutagenic, cancer inhibiting properties in many studies (Marnewick et al., 2011; Pantsi et al., 2011; Lawal et al., 2019a). This present study examined the antioxidant potential of an aqueous extract from commercially available rooibos tea on DEP-induced oxidative stress in hepatic tissue of exposed rats and the role of Nrf2-dependent antioxidant in this protection.

\section{MATERIALS AND METHODS}

Chemicals: Aspartate aminotransaminase (AST) and alanine aminotransaminase assay kits were obtained from Agape Diagnostics (Switzerland $\mathrm{GmbH}$ ). Primers against rat's cDNA were brought from Inqababiotec (Hatfield, South Africa). RNA isolation TRI Reagent ${ }^{\circledR}$ was purchased from Zymo Research (USA). ProtoScript II First Strand cDNA Synthesis Kit, Luna Universal qPCR Master Mix and quick-load purple 100 bp DNA ladder were bought from BioLabs (New England). All other reagents were brought from Sigma-Aldrich (Germany).

Collection of DEP and preparation of methanol extract: DEP was collected in Akure, Ondo State, 
Nigeria from a MAN tipper truck (1996 model, engine number G0967). The collection of the particles from a running engine was done as previously described $(\mathrm{Li}$ et al., 2004) and the collected particles were stored at $-80^{\circ} \mathrm{C}$ away from sunlight. The preparation of the methanol extract of the particles was done as previously described (Lawal et al., 2015). The dried extract was reconstituted in DMSO as $100 \mu \mathrm{g}$ dried extract/ $\mu 1$ DMSO and stored away from sunlight at $80^{\circ} \mathrm{C}$ for further use. The redox (oxidative) potential and the polycyclic aromatic hydrocarbons (PAHs) content of the extract had been previously characterised (Lawal et al., 2019b).

Aqueous rooibos extract (RE) preparation: Rooibos tea pack (containing 20 tea bags, batch number 6001156905236), a product of Entryce beverages, South Africa, was purchased from the shoprite shopping mall, Akure, Ondo-State, Nigeria. After pooling the contents of the 20 tea bags together, it was boiled in water at a concentration of $1 \mathrm{~g} / 20 \mathrm{ml}$ distilled water for $15 \mathrm{~min}$. After cooling to room temperature, the solution was filtered using Whatmann paper and then solidified using rotary evaporator. The solidified samples were reconstituted in $0.9 \%$ saline solution to $10 \mathrm{mg} / \mathrm{ml}$ stock and kept at $-20^{\circ} \mathrm{C}$ for further use.

Exposure protocol and tissue collection: Animals treatments were done according to approved protocols of the Animal Ethics Committee of School of Sciences, Federal University of Technology Akure (FUTA). Six (6)-week-old male wistar rats were assigned into 4 groups (n=6/group) that were exposed to the following: (1) Saline for 4 weeks and DMSO for the last 2 weeks (control), (2) $50 \mathrm{mg} / \mathrm{kg} \mathrm{RE}$ for 4 weeks, (3) $50 \mathrm{mg} / \mathrm{kg} \mathrm{RE}$ for 2 weeks followed by concomitant exposure to $50 \mathrm{mg} / \mathrm{kg} \mathrm{RE}$ and $0.7 \mathrm{mg} / \mathrm{kg}$ DEP (twice a week) for 2 additional weeks, and (4) 0.7 $\mathrm{mg} / \mathrm{kg}$ DEP for 2 weeks (twice a week).RE was administered orally, while DEP was given subcutaneously. The rats were sacrificed by cervical dislocation $24 \mathrm{hr}$ after the last dose and blood were collected from the heart. Liver tissues were excised and stored at $-80^{\circ} \mathrm{C}$ for further analysis.

AST and ALT assays: AST and ALT activities in the serum were assayed using Agape reagent kit (Agape Diagnostics, Switzerland $\mathrm{GmbH}$ ) as previously described (Reitman and Frankel, 1957).

Oxidative stress measurement: The oxidative damage to membrane lipid was assessed by lipid peroxidation assay using thiobarbituric acid (TBA) method (Yagi, 1976). The conjugated dienes (CDs) levels were assayed as described by Buege and Aust (1978). Reduced glutathione (GSH) content was determined by modified method of Asensi et al (1999).Protein determination was done using Bradford method (1976).
Real time-quantitative polymerase reaction (RT$q P C R)$ for gene expression analysis: TRI Reagent ${ }^{\circledR}$ (Zymo Research, USA) was used to isolate total RNA from the liver tissues as previously described (Ramalho et al., 2004). cDNA was synthesized using $1 \mu \mathrm{g}$ of the isolated RNA within the purity range of 1.8-2.0. Synthesis was carried out in Multigene ${ }^{\mathrm{TM}}$ Mini thermal cycler (Labnet Int'l Inc., USA) using the ProtoScript II First Strand cDNA Synthesis Kit (BioLabs, New England) in a 3-step reaction condition: $65^{\circ} \mathrm{C}$ for $5 \mathrm{~min}, 42^{\circ} \mathrm{C}$ for $1 \mathrm{hr}$ and $80^{\circ} \mathrm{C}$ for 5 min. RT-qPCR for gene expression analysis was carried out on a StepOnePlus Applied Biosystem qPCR system according to the manufacturer's protocols. Primers to the rat's cDNA were listed in Table 1 and purchased from Inqababiotec (Hartield, South Africa). The Luna Universal qPCR Master Mix (BioLabs, New England) was used for the real timequantitative PCR (RT-qPCR) reaction and PCR conditions were as follows: 1 cycle at $95^{\circ} \mathrm{C}$ for $3 \mathrm{~min}$, 40 cycles at $95^{\circ} \mathrm{C}$ for $15 \mathrm{sec}, 40$ cycles at $60^{\circ} \mathrm{C}$ for 30 sec, and 40 cycles at $72^{\circ} \mathrm{C}$ for $30 \mathrm{sec}$. Comparative cycle threshold $(\triangle \Delta \mathrm{CT})$ method was used to quantify the relative amount of mRNA in the sample and gene expression was normalised with $\beta$-actin gene as housekeeping gene. The PCR product was run in $0.8 \%$ agarose gel stained with ethidium bromide.

Table 1: Primer sequence for real time quantitative PCR

\begin{tabular}{|c|c|}
\hline Gene & Sequence \\
\hline \multirow[t]{2}{*}{$\beta$-actin } & Forward: CTCCCTGGAGAAGAGCTATGA \\
\hline & Reverse: AGGAAGGAAGGCTGGAAGA \\
\hline \multirow[t]{2}{*}{ Nrf2 } & Forward: ACGTGATGAGGATGGGAAAC \\
\hline & Reverse: TATCTGGCTTCTTGCTCTTGG \\
\hline \multirow[t]{2}{*}{ HO-1 } & Forward: GATGGCCTCCTTGTACCATATC \\
\hline & Reverse: AGCTCCTCAGGGAAGTAGAG \\
\hline
\end{tabular}

Statistical analysis: GraphPad Prism5 Software was used for statistical analysis. Analysis was done using one-way analysis of variance (ANOVA) and comparison between group pairs was carried out with the Bonferroni post-hoc test. Data were expressed as mean \pm SEM and differences were considered statistically significant at the $\mathrm{p}$-value of $<0.05$.

\section{RESULTS AND DISCUSSION}

The present study investigates the protective effects of aqueous rooibos extract on diesel exhaust particles induced hepatic oxidative stress in exposed wistar rats. The data indicate that while DEP-induced significant hepatotoxic effect and oxidative stress, the presence of aqueous rooibos extract attenuated these effects.

To assess the protective effects of rooibos extract on diesel exhaust particles-induced hepatotoxicity, the serum levels of AST and ALT in rats exposed to 0.7 $\mathrm{mg} / \mathrm{kg}$ DEP in the presence and absence of $50 \mathrm{mg} / \mathrm{kg}$ aqueous rooibos extract were determined (Fig. 1). The data showed that DEP caused a 1.52- and 2.31-fold significant $(\mathrm{p}<0.001)$ increase in serum AST (Fig 1A) 
and ALT (Fig. 1B) activities respectively, when compared to control. The data also showed that pretreatment with aqueous rooibos extract significantly $(\mathrm{p}<0.001)$ caused a 1.55 - and 1.42-fold decrease in serum AST and ALT activities when compared to DEP exposure only (Fig.1A \& B),
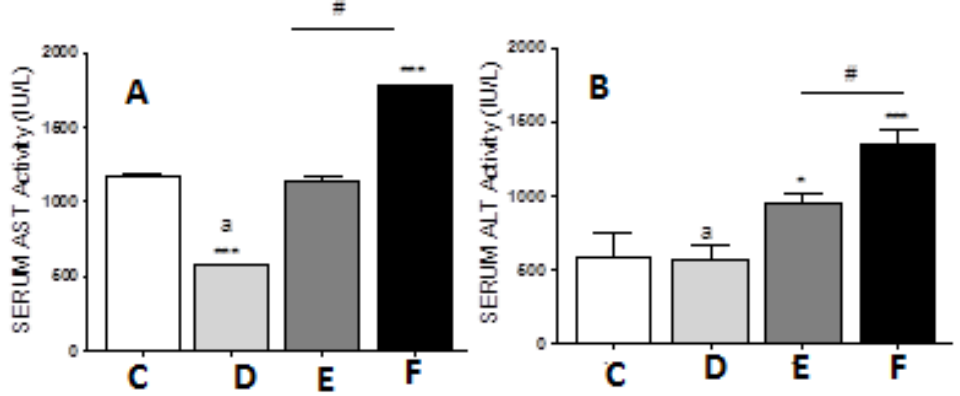

Fig 1. Effects of aqueous rooibos tea extract on DEP-induced serum AST and ALT activities: $C=0 ; D=R E(50 \mathrm{mg} / \mathrm{kg}) ; \mathrm{E}=\mathrm{RE}(50$ $\mathrm{mg} / \mathrm{kg})+\mathrm{DEP} 0.7 \mathrm{mg} / \mathrm{kg} ; \mathrm{F}=$ DEP $0.7 \mathrm{mg} / \mathrm{kg}$

Wistar rats were exposed to $0.7 \mathrm{mg} / \mathrm{kg}$ DEP in the presence and absence of $50 \mathrm{mg} / \mathrm{kg}$ rooibos tea extract. (A) AST and (B) ALT activities were determined in the serum as described in the materials and methods. Values are mean \pm SEM of three different experiments done in triplicate $(n=3) .{ }^{*} p<0.05$, $* * p<0.01, * * * p<0.001$ as significant difference as compared to the controls. ${ }^{*} p<0.001$ as significant difference between rooibos extract pre-treatment vs DEP, ${ }^{a} p<0.01$ as significant difference between rooibos extract pre-treatment vs rooibos extract

Exposure of rats to nanoparticle rich-diesel exhaust has been reported to increase serum ALT and AST activities (Ito et al., 2016). The present study was in agreement with this earlier study. In the present study, DEP caused significant increase in ALT and AST activities, which is a measured of liver damage. Though some studies have shown the use of endogenous and exogenous antioxidants to protect against diesel exhaust particles induced damage (Tseng et al., 2015; Lawal et al., 2015), no study has yet reported on the effects of rooibos extract on the activity of the serum enzymes biomarkers of the hepatotoxic effect of diesel exhaust particles. This study showed that rooibos extract attenuates the effects of DEP on serum ALT and AST activities, indicating the hepato-protective role of rooibos extract on diesel exhaust particles induced hepatic damage. These findings were in agreement with the reported health promoting effects of rooibos in mice and humans (Watanabe et al., 2014; Marnewick et al., 2011).

Several studies have implicated oxidative stress in the adverse health effects of diesel exhaust particles
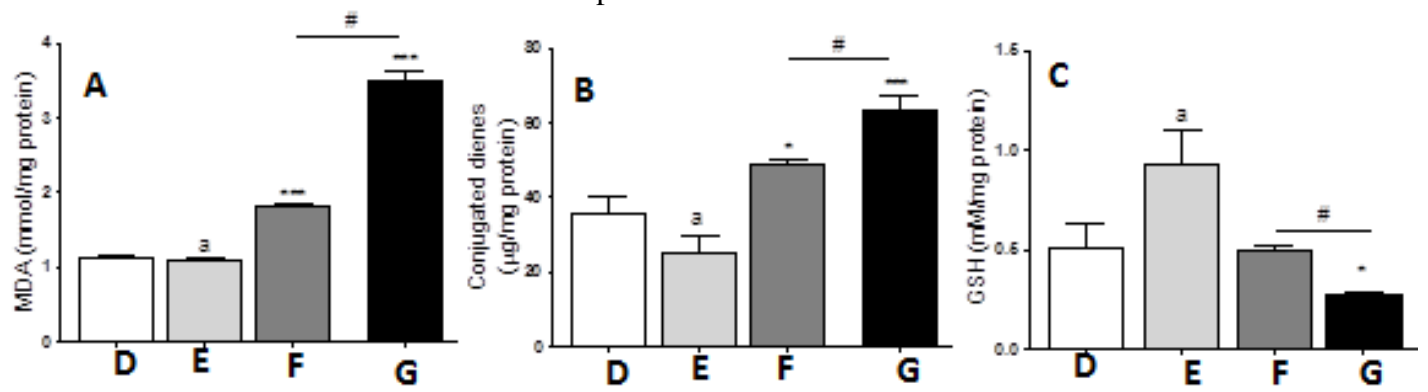

Fig 2. Effects of aqueous rooibos tea extract on DEP-induced hepatic oxidative stress $D=0 ; E=R E(50 \mathrm{mg} / \mathrm{kg}) ; \mathrm{F}=\mathrm{RE}(50 \mathrm{mg} / \mathrm{kg})+\mathrm{DEP}$ $0.7 \mathrm{mg} / \mathrm{kg} ; \mathrm{G}=$ DEP $0.7 \mathrm{mg} / \mathrm{kg}$

Wistar rats were exposed to $0.7 \mathrm{mg} / \mathrm{kg}$ DEP in the presence and absence of $50 \mathrm{mg} / \mathrm{kg}$ rooibos tea extract. (A) MDA, (B) CDs and (C) GSH levels were determined in the homogenised liver tissue as described in the materials and methods. Values are mean $\pm S E M$ of three different experiments done in triplicate $(n=3) .{ }^{*} p<0.05, *^{*} p<0.01, *^{*} p<0.001$ as significant difference as compared to the controls. ${ }^{*} p<0.001$ as significant difference between rooibos extract pre-treatrment vs $D E P,{ }^{a} p<0.01$ as significant difference between rooibos extract pre-treatment vs rooibos extract. 
The present study also showed that diesel exhaust particles caused significant $(\mathrm{p}<0.05)$ decrease $(1.62-$ fold) in the reduced glutathione (GSH) level in the liver (Fig.2C). Pre-treatment with $0.7 \mathrm{mg} / \mathrm{kg}$ rooibos extract, however, caused a significant $(\mathrm{p}<0.01)$ elevation in the intracellular GSH level compared to DEP exposure only (Fig. 2C). GSH is an important endogenous antioxidant that has been implicated in the maintenance of redox homeostasis (Lawal et al., 2017). Depletion of GSH level with accumulation of oxidised glutathione (GSSG) is a hallmark of oxidative stress. In the present study, diesel exhaust particles caused significant depletion in hepatic GSH levels and this may account for the increased oxidative damage in the liver. This result was in consistent with other studies that have shown depletion in GSH and accumulation of GSSG in DEP exposure (Lawal et al., 2016; Tobwala et al., 2013; Tseng et al., 2015). The pre-treatment with aqueous rooibos extract, however, significantly reversed this DEP-induced GSH reduction, confirming the antioxidant potential of the extract. These data was consistent with the clinical data that showed the GSH boosting activity in the serum of subjects given oral dose of rooibos herbal tea (Marnewick et al., 2011).

$\mathrm{Nrf} 2$ is an important transcription factor that regulates the gene expression of antioxidant enzymes. We have shown that exposure of $\mathrm{Apoe}^{-/-}$(null) mice to diesel exhaust caused induction in Nrf2, HO-1, NQO1, GCLC and SOD1 genes in the liver (Yin et al., 2013; Miller et al., 2013). Consistent with these findings, the present study shows that diesel exhaust particles induced hepatic expression of Nrf2 and HO-1 genes probably in response to oxidative stress. The results showed that diesel exhaust particles induced hepatic expression of Nrf2 and HO-1 genes significantly $(\mathrm{p}<0.001)$ by $1.74-$ and 2.07- fold respectively, when compared to control (Fig. 3A \& 4A).
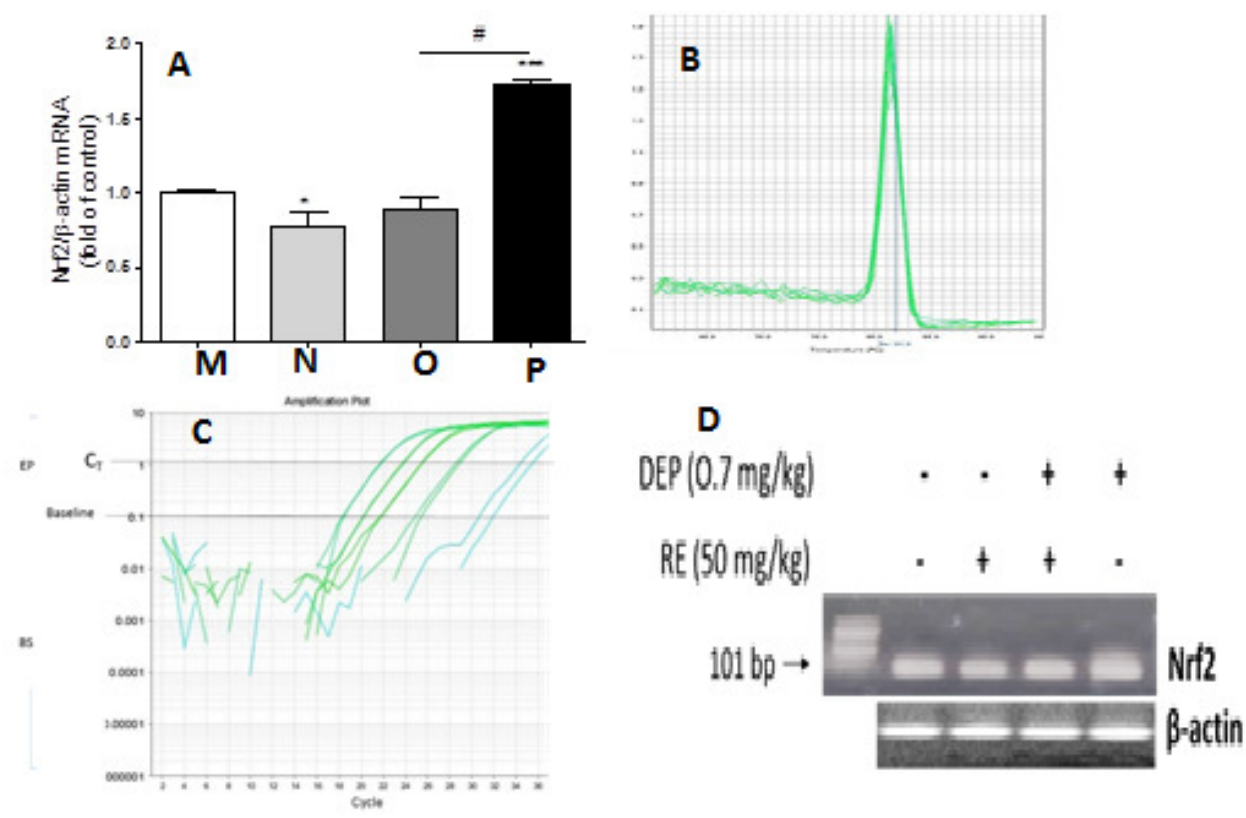

Fig 3. Effects of rooibos extract on Nrf2 gene expression in the presence of DEP $(M=0 ; \mathrm{N}=\mathrm{RE} 50 \mathrm{mg} / \mathrm{kg} ; \mathrm{O}=\mathrm{RE} 50 \mathrm{mg} / \mathrm{kg}+\mathrm{DEP} 0.7$ $\mathrm{mg} / \mathrm{kg} ; \mathrm{P}=\mathrm{DEP} 0.7 \mathrm{mg} / \mathrm{kg})$

(A) Relative quantification of Nrf2 gene expression from the $C_{T}$ values of cDNA obtained from the liver of rats exposed to $0.7 \mathrm{mg} / \mathrm{kg}$ DEP in the presence and absence of $50 \mathrm{mg} / \mathrm{kg}$ rooibos tea extract using $\mathrm{Nrf} 2$ primers and $\beta$-actin as endogenous reference. Values are mean $\pm S E M$ of three different experiments done in triplicate $(n=3)$. ${ }^{*} p<0.05, * * p<0.01, * * * p<0.001$ as significant difference as compared to the controls. ${ }^{\#} p<0.001$ as significant difference between rooibos extract pre-treatment $v$ s DEP, ${ }^{a} p<0.01$ as significant difference between rooibos extract pre-treatment vs rooibos extract. (B) Instrument-derived melt curve showing a single amplification product (single peak) (C) Instrument derived amplification curve. (D) agarose gel analysis of the qPCR product (101 bp). BS, background signal; EP, exponential phase; Rn, emission intensity of the reporter/emission intensity of passive reference (normalised reporter); $\Delta R n$, the difference between the Rn at the end point and at the starting point and it is directly proportional to the DNA amount during the exponential phase.

The presence of rooibos extract, however, caused a significant $(\mathrm{p}<0.001)$ 2.23- and 1.32- fold decrease in hepatic Nrf2 and HO-1 gene expression induced by diesel exhaust particles respectively (Fig, 3A \& 4A). The melting curves obtained from the qPCR instrument showed that only the desired ampliconsNrf2 (Fig. 3B) and HO-1 (Fig. 4B)- were amplified during the qPCR runs. Also, the instrument derived amplification curves showed that there were amplifications of the Nrf2 (Fig. 3C) and the HO-1 (Fig. 4C) genes during the qPCR runs. The results of the RT-qPCR were confirmed by the agarose gel analysis of the Nrf2 (Fig. 3D) and HO-1 (Fig. 4D), which gave the amplicon sizes of $101 \mathrm{bp}$ (Nrf2) and $99 \mathrm{bp}$ (HO-1). 

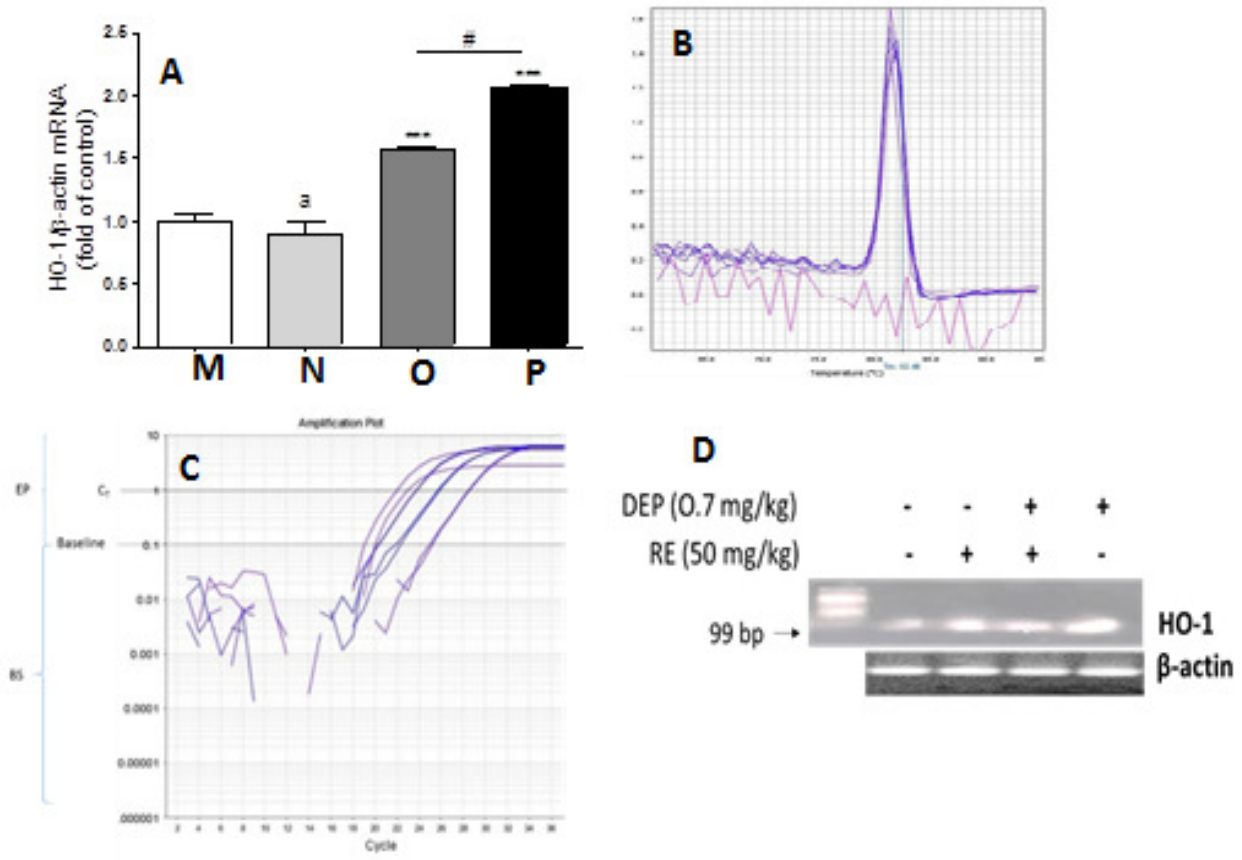

Fig 4. Effects of rooibos extract on HO-1 gene expression in the presence of DEP.(M=0; $\mathrm{N}=\mathrm{RE} 50 \mathrm{mg} / \mathrm{kg} ; \mathrm{O}=\mathrm{RE} 50 \mathrm{mg} / \mathrm{kg}+\mathrm{DEP} 0.7$ $\mathrm{mg} / \mathrm{kg} ; \mathrm{P}=\mathrm{DEP} 0.7 \mathrm{mg} / \mathrm{kg})$

(A) Relative quantification of $\mathrm{Nrf} 2$ gene expression from the $C_{T}$ values of cDNA obtained from the liver of rats exposed to $0.7 \mathrm{mg} / \mathrm{kg} D E P$ in the presence and absence of $50 \mathrm{mg} / \mathrm{kg}$ rooibos tea extract using $\mathrm{HO}-1$ primers and $\beta$-actin as endogenous reference. Values are mean $\pm S E M$ of three different experiments done in triplicate $(n=3)$. ${ }^{*} p<0.05, * * p<0.01, * * * p<0.001$ as significant difference as compared to the controls. ${ }^{\#} p<0.001$ as significant difference between rooibos extract pre-treatment vs DEP, ${ }^{a} p<0.01$ as significant difference between rooibos extract pre-treatment vs rooibos extract. (B) Instrument-derived melt curve showing a single amplification product (single peak). (C) Instrument derived amplification curve. (D) agarose gel analysis of the qPCR product $(99 \mathrm{bp}) . \mathrm{BS}$, background signal; EP, exponential phase; Rn, emission intensity of the reporter/emission intensity of passive reference (normalised reporter); $\Delta R n$, the difference between the Rn at the end point and at the starting point and it is directly proportional to the DNA amount during the exponential phase.

We have also shown that the induction of HO-1 protects against diesel exhaust particles induced oxidative damage in human microvascular endothelial cells (Lawal et al., 2015). In addition, studies have shown that administration of exogenous antioxidants are effective in protecting against diesel exhaust particles induced oxidative stress in different endothelial cells (Frikke-Schmidt et al., 2011; Li et al., 2009; Tseng et al., 2015).

Consistent with these studies, the present study showed that the use of rooibos extract protects against the oxidative stress induced by diesel exhaust particles in hepatic cells. However, this protection does notinvolve the up regulation of Nrf2 and HO-1 from the levels seen in diesel exhaust particles exposure. Thus, the protective effects of the extract may be due to the activity of its antioxidant phytochemicals, which has earlier been reported by Marnewick (2009)

Conclusion: In conclusion, these data seem to suggest that rooibos extract exerts protection against DEPinduced hepatic oxidative stress without triggering the up-regulation of Nrf2 mediated pathways. Therefore, rooibos tea may provide an alternate therapeutic approach to combating the adverse health effects of diesel exhaust particulate matter on hepatic tissue.

\section{REFERENCES}

Asensi, M; Sastre, J; Pallardo, V; Lloret, A; Lehner, M; Asuncion, JG; Vina, J (1999).Ratio of reduced to oxidized glutathione as indicator of oxidative stress status and DNA damage. Methods Enzymol. 299: 267-277.

Bradford, MM (1976). A rapid and sensitive method for protein quantification of microgram quantities of protein utilizing the principle of protein-dye binding. Anal. Biochem. 72: 248-254.

Buege, JA; Aust, SD (1978). Microsomal Lipid Peroxidation. Methods Enzymol. 52: 302-310.

Dybdahl, M; Risom, L; Moller, P; Autrup, H; Wallin, H; Vogel, U; Bornholdt, J; Daneshvar, B; Dragsted, LO; Weimann, A; Poulsen, HE; Loft, S (2003). DNA adduct formation and oxidative stress in colon and liver of Big Blue ${ }^{\circledR}$ rats after dietary exposure to diesel particles. Carcinogenesis 24 (11): 1759-1766.

Frikke-Schmidt, H; Roursgaard, M; Lykkesfeldt, J; Loft, S; Nøjgaard, JK; Møller, P(2011). Effect of vitamin $\mathrm{C}$ and iron chelation on diesel exhaust particle and carbon blackinducedoxidative damage and cell adhesionmolecule expression in 
human endothelialcells. Toxicol. Lett. 203: 181189.

Joubert, E; Gelderblom, WCA; Louw, A; De Beer, D(2008). South African herbal teas.J. Ethnopharmacol. 119: 376-412.

Reitman, SS; Frankel, S(1957). A calorimetric method for the determination serumtransaminase activity. Amer. J. Clin. Path. 28: 56-68.

Ito, Y; Yanagiba, Y; Ramdhan, DH; Hayashi, Y; Li, Y; Suzuki, AK; Kamijima, M; Nakajima, T(2016). Nanoparticle rich diesel exhaustinduced liver damage via inhibitedtransactivation of peroxisome proliferator activated receptor alpha. Environ. Toxicol 31: 1985-1995.

Lawal, AO; Davids, LM; Marnewick, JL (2019a). Rooibos (Aspalathus linearis) and honeybush (Cyclopia species) modulate the oxidative stress associated injury of diesel exhaust particles in human umbilical vein endothelial cells. Phytomedicine 152898. https://doi.org/10.1016/j.phymed.2019.152898.

Lawal, AO; Oluyede, DM; Adebimpe, MO; Olumrgbon, LT; Awolaja, OO; Elekofehinti, OO; Crown, OO (2019b). The cardiovascular protective effects of rooibos (Aspalathus linearis) extract on diesel exhaust particles induced inflammation and oxidative stress involve NF-KBand Nrf2-dependent pathways modulation. Heliyon. e01426. https://doi.org/10.1016/j.heliyon.2019.e01426

Lawal, AO(2017). Air particulate matter induced oxidative stress and inflammation in cardiovascular disease and atherosclerosis: The role of Nrf2 and AhR-mediated pathways. Toxicol. Lett. 270: 88-95.

Lawal, AO; Davids, LM; Marnewick, JL (2016). Diesel exhaust particles and endothelial cells dysfunction: An update. Toxicol. In virto 32: 92104.

Lawal, AO; Zhang, M; Dittmar, M; Lulla, A; Araujo, JA(2015).Heme oxygenase-1protects endothelial cells from the toxicity of air pollutant chemicals. Toxicol. Appl. Pharmacol. 284(3):281-291.

Li, C; Lee, C; Cheng, Y; Juang, H; Kang, J(2004). Activation and up-regulation of nitricoxide synthase in human umbilical vein endothelial cells by polycyclic aromatic hydrocarbons.Toxicol. Lett. 151: 367-374.

Li, R; Ning, Z; Cui, J; Khalsa, B; Ai, L; Takabe, W; Beebe, T; Majumdar, R; Sioutas, C; Hsiai,
$\mathrm{T}(2009)$. Ultrafine particles from diesel engines induce vascular oxidative stress via JNK activation. Free Radic. Biol. Med. 46: 775-782.

Marnewick, JL (2009). Rooibos and Honeybush: Recent Advances in Chemistry, Biological Activity and Pharmacognosy. In: ACS Symposium Series, Vol. 1021.DOI: 10.1021/bk-20091021.ch016. pp 277-294.

Marnewick, JL; Rautenbach, F; Venter, I; Neethling, H; Blackhurst, DM; Wolmarans, P; Macharia, M (2011). Effects of rooibos (Aspalathuslinearis) on oxidative stress and biochemical parameters in adult at risk for cardiovascular disease. $J$ Ethnopharmacol. 133: 46-52.

Miller, MR; McLean, SG; Duffin, R; Lawal, AO; Araujo, JA; Shaw, CA; Mills, NL; Donaldson, K;Newby, DE; Hadoke, PWF(2013). Diesel exhaust particulate increases the size and complexity of lesions in atherosclerotic mice. Part. Fibre Toxicol 10: 61

Montiel-Davalos, A; Ibarra-Sanchez Mde, J; VenturaGallegos, JL; Alfaro-Moreno, E; Lopez-Manure, $\mathrm{R}(2010)$. Oxidative stress and apoptosis are induced in human endothelial cells exposed to urban particulate matter. Toxicol. In vitro 24: 135 141.

Pantsi, WG; Marnewick, JL;Esterhuyse, AJ; Rautenbach, F; Van Rooyen, J (2011).Rooibos (Aspalathuslinearis) offers cardiac protection against ischaemia/reperfusion in theisolated perfused rat heart. Phytomedicine 18: 1220-1228.

Pradedova, EV; Isheeva, OD; Salyaev, RK(2011). Classification of the antioxidant defensesystem as the ground for reasonable organization of experimental studies of the oxidative stress in plants. Russ. J. Plant Physiol 58: 210-217.

Ramalho, AS; Beck, S; Farinha, CM; Clarke, LA; Heda, GD; Sterner, B; Sanz, J; Gallati, S; Amaral, MD; Harris, A; Tzetis, M(2004). Methods for RNA extraction, cDNA preparation and analysis of CFTR transcripts. J. Cyst Fibros. Suppl 2: 1115.

Tobwala, S; Zhang, X; Zheng, Y; Wang, H; Banks, WA; Ercal, N(2013). Disruption of theintegrity and function of brain microvascular endothelial cells in culture by exposure to diesel engine exhaust particles. Toxicol. Lett 220: 1-7.

Tseng, CY; Chang, JF; Wang, JS; Chang, YJ; Gordon, MK; Chao, MW (2015). Protective effects of Nacetylcysteine against diesel exhaust particlesinduced intracellular ROSgenerates pro- 
inflammatory cytokines to mediate the vascular permeability of capillary-like endothelial tubes. $\begin{array}{llll}P L o S & \text { One } & \end{array}$ http://dx.doi.org/10.1371/journal.pone.0131911.

Watanabe, N; Hara, Y; Sakuda, S; Mori, Y; Furuya, Y; Watanabe, T (2014). Effects of Dietary Green

Rooibos on Physical Endurance in Swimming Mice. Food Nutr. Sci. 5: 127-131.

Yagi, K (1976). A simple fluorometric assay for lipoperoxide in blood plasma. Biochemia. Medica.15:212-216.
Yin, F; Lawal, A; Ricks, J; Fox, R; Larson, T; Navab, M; Fogelman, M; Rosenfeld, ME; Araujo, JA(2013). Diesel exhaust induces systemic lipid peroxidation and development ofdysfunctional prooxidant and proinflammatory high-density lipoprotein. ArteriosclerThrombVasc Biol. 33: 1153-1161.

Yoshizaki, K; Brito, JM;Toledo, AC; Nakagawa, NK; Piccin, VS; Junqueira, MS; Negri, EM;Carvalho, ALN; Ligeiro de Oliveira, AP; Tavares de Lima, W; Saldiva, PHN; Mauad, T; Macchione, M (2010). Subchronic effects of nasally instilled diesel exhaust particulates on the nasal and airway epithelia in mice. Inhal. Toxicol. 22 (7): 610-617. 